\title{
ADMINISTRATIVE LAW - A TOOL FOR SOCIAL JUSTICE AND TRANSFORMATIVE CONSTITUTIONALISM: THE IMPLICATIONS OF MELANI V THE CITY OF JOHANNESBURG
}

by Nelsie Siboza*

\section{Introduction}

This case note will consider the decision of the High Court in the case Melani $v$ City of Johannesburg. ${ }^{1}$ I ask whether the Court's decision is in accordance with progressive substantive aspirations of the Constitution of the Republic of South Africa, $1996 .{ }^{2}$ In particular, I consider whether the Court's decision was overly formalistic, whether it met with the requirements of transformative constitutionalism within the context of administrative law and whether the decision furthered social justice. I will start with a brief summary of the facts, the legal question and the decision of the Court in section 2. Section 3 will follow with a consideration of the notion of transformative constitutionalism regarding adjudication within the context of administrative law and social justice. An analysis of whether the Court did in fact further transformative constitutionalism will be discussed in section 4. Finally, I will conclude my discussion in section 5.

\section{Summary of the case}

The applicants in the Melani case were approximately 10000 poor people living in households in Slovo Park. ${ }^{3}$ They have been residing in Slovo Park for a number of years and have been living in deplorable health and safety conditions. ${ }^{4}$ The legislative and policy framework ${ }^{5}$ provides in section 9(a)(i) of the National Housing Act 107 of 1997 (the Housing Act) that the City needs to take all reasonable steps within the framework of national and provincial housing legislation and policy to ensure that the inhabitants of its area have access to

3rd year LLB student at University of Pretoria.

[2016] ZAGPJHC 55, 22 March 2016.

Act 109 of 1996.

Melani (n 1 above) para 3.

As above.

5 The Housing Act requires the Minister to determine national housing policy by approving projects that are consistent with it and the City to implement national housing policy. 
adequate housing on a progressive basis. The Act $^{6}$ consists of a wide range of procedures, plans and fundamental instruments which are designed to facilitate the delivery of adequate housing to people who are in need, such as the residents of Slovo Park. ${ }^{7}$

The main issue of contestation in this case was whether the decision taken by the City to relocate the residents of Slovo Park to Unaville met with the administrative law standards of lawfulness and fairness. ${ }^{8}$ The Court found the City's decision to relocate the residents of Slovo Park to Unaville to be unreasonable and unlawful. The Court held further that this decision was taken outside the scope of the relevant legislative and policy framework.

\section{Transformative constitutionalism, administrative law and social justice}

Because of South Africa's past institutionalised and legitimised racism, ${ }^{9}$ poverty eradication forms an integral part of the conception of South Africa's post-apartheid constitutionalism. ${ }^{10}$ It is indisputable that the right to have access to adequate housing aids in the eradication of poverty and thus furthers social justice. ${ }^{11}$ The Constitution evinces a deep concern for the material inequality closely associated with past exclusion and poverty that is manifested by the lack of proper housing. ${ }^{12}$ The residents of Slovo Park are a clear example of the unchanged living conditions for many black citizens to whom apartheid's multiple legacies continue to be a lived and living reality. ${ }^{13}$ The question thus is whether the Court in this case adopted a transformative and progressive approach in its interpretation in aiding poverty eradication and thus advancing social justice and transformative adjudication or whether it succumbed to a formalistic approach.

Transformative constitutionalism involves the eradication of systematic forms of domination and material disadvantages based on race, gender, class and other forms of inequality. ${ }^{14}$ Adopting a transformative approach entails both social and economic change ${ }^{15}$ which echoes both Klare's and Langa's call for a change in the legal

Act 107 of 1997.

Melani (n 1 above) para 6.

Melani (n 1 above) para 24.

1995 (3) SA 391 para 262.

10 S Sibanda 'Not purpose-made! Transformative constitutionalism, postindependence constitutionalism and the struggle to eradicate poverty' 20113 Stellenbosch Law Review 483.

111998 (1) SA 765 (CC) para 8.

122010 (3) SA 454 (CC) para 142.

13 Sibanda (n 10 above) 485.

14 P Langa 'Transformative constitutionalism' 20063 Stellenbosch Law Review 352.

15 Sibanda (n 10 above) 485. 
culture in order to realise transformative constitutionalism. In essence, it further encapsulates Moseneke's ideal of transformative adjudication $^{16}$ as it promotes a thorough engagement with the Constitution and its progressive and social aspirations. ${ }^{17}$ It is the complete departure from conservative legal culture ${ }^{18}$ which also involves a change in legal education by changing the mindset of legal scholars and legal practitioners; not just simply changing the laws. ${ }^{19}$

The Constitution's transformative mandate entails a commitment to 'social transformation' through 'substantive adjudication,'20 particularly in cases such as the Melani case, concerning the right of access to adequate housing, because it is one of the most prevalent social issues in South Africa. ${ }^{21}$ This transformative mandate is achievable by means of transformative adjudication, ${ }^{22}$ which requires an evolved, updated and politicised account of the rule of law ${ }^{23}$ as opposed to the rigidity of formalism. ${ }^{24}$ The notion of transformative constitutionalism places a responsibility on judges to justify their decisions not only by reference to authority, such as policy and legislative framework, but also by reference to values enshrined in the Constitution. ${ }^{25}$ This is an imperative aspect of transformative constitutionalism in its commitment to substantive equality and improving socio-economic conditions. ${ }^{26}$

The Constitution holds both substantive and progressive aspirations, ${ }^{27}$ which are ultimately intended to advance social justice. One of the substantive and progressive aspirations that the Constitution holds is to realise the right to access adequate housing. Social justice can be given many definitions but, for purposes of this article, the definition of social justice is limited to the eradication of poverty and the realisation of the constitutional right of access to adequate housing, which aids in the eradication of poverty, and thus advances social justice as entailed in section 26(1) of the Constitution.

16 D Moseneke 'Fourth Bram Fischer memorial lecture: Transformative adjudication' 200218 South African Journal on Human Rights 310.

17 C Hoexter 'Judicial policy revisited: Transformative adjudication in administrative law' 200824 South African Journal on Human Rights 286.

18 Langa (n 14 above) 356.

19 As above.

20 M Murcott 'A future for the doctrine of substantive legitimate expectation? The implications of KwaZulu Natal Joint Liaison Committee $v$ MEC for Education, KwaZulu Natal' 2015 (18)1 Potchefstroom Electronic Law Journal 3143.

21 Melani (n 1 above) para 3.

22 Moseneke (n 16 above) 310.

23 K Klare 'Legal culture and transformative constitutionalism' 1998 (14) South African Journal on Human Rights 188.

24 Murcott (n 20 above) 3143.

25 Langa (n 14 above) 356

26 As above.

27 Klare (n 23 above) 188. 
The question therefore is whether the Court's reasoning and its manner is substantive as opposed to formalistic and, furthermore, whether the Court furthered transformative constitutionalism, and consequentially, advanced social justice?

\section{Did the Court in the Melani case further transformative constitutionalism and social justice?}

The Court in the Melani case reasoned that the City's failure to apply the Upgrading of Informal Settlements Policy (the UISP) was unreasonable and unlawful. The decision by the City to relocate the residents of Slovo Park was taken outside the legislative and policy framework intended to apply to informal settlements such as Slovo Park. ${ }^{28}$ Furthermore, the Court found the City's actions to be unreasonable because it deprived the residents' right to just administrative action, procedurally, and substantively, deprived the residents' right of access to adequate housing in terms of section 26(1) of the Constitution. ${ }^{29}$

The Court here has acknowledged the interconnectedness of rights. ${ }^{30}$ These rights are the right to just administrative action as envisaged in section 33 of the Constitution and the right to access adequate housing. These two rights are not pigeonholed ${ }^{31}$ and need not be treated as mutually exclusive. Instead, the Court used the right to just administrative action to advance for the right of access to adequate housing and therefore social justice.

The doctrine of legitimate expectation entails that a reasonable expectation, based on a well-established practice or an express promise by an administrator acting lawfully, gives rise to legal protection when the practice or promise is clear, unambiguous and unqualified. ${ }^{32}$ Furthermore, the legal protection afforded usually takes the form of ordering that a fair procedure be followed before a decision is made in respect of the expected conduct. ${ }^{33}$

The legitimate expectation of the residents of Slovo Park in the Melani case was the City's obligated conduct to follow the procedures stipulated in the UISP regarding the upgrading of Slovo Park. The City's failure to take a decision to act in terms of the UISP was unlawful due to the fact that the City was in breach of the applicable

30 C Hoexter Constitutional Court' 2008 (1) Constitutional Court Review 228.

31 Hoexter (n 30 above) 228.

32 Murcott (n 20 above) 3136.

33 As above. 
statutory framework for the upgrading of informal settlements. ${ }^{34}$ At the time the application was launched, the City had neither refused to apply the UISP nor agreed to do so - the only decision the City had taken was to relocate the residents to Unaville, stating that it was suitable for development. ${ }^{35}$ The UISP makes it clear that relocation of informal settlements should be the exception and not the rule. It also states that relocation must take place at a location as close as possible to the existing settlement and within the context of community approved strategies. ${ }^{36}$

The Court in the Melani case further found the City's conduct to be subject to the reasonableness criterion. 37 The reasonableness criterion echoes the justification principle that all arms of government are expected to adhere to. ${ }^{38}$ When assessing whether the government meets with its obligations to act reasonably under section 26(2) of the Constitution, the measure it adopts must be comprehensive, coherent, inclusive, balanced, flexible, transparent and properly conceived and properly implemented. This therefore promotes transparency and accountability, which are two of the few democratic values that the Constitution enshrines.

The Court further stated that the measure adopted must be tailored to the particular context (as opposed to a mere formal application) in which they apply, as what may be appropriate in a rural area may not be appropriate in an urban setting. ${ }^{39}$ The Court found the City's unilateral decision to relocate only qualifying beneficiaries to Unaville to be unreasonable and not inclusive. ${ }^{40}$ The Court further found that this decision completely contradicted the established constitutional jurisprudence regarding the need for engagement in instances where the right to adequate housing is concerned. ${ }^{41}$

It is clear that the Court not only took the legislative and policy frameworks of the UISP into account but also considered the substantive surrounding circumstances. One of the substantive surrounding circumstances was the fact that the residents had been told for a period of more than 20 years that their households would be upgraded. ${ }^{42}$ Based on the procedural requirements set out in the UISP as well as the substantive surrounding circumstances in this matter,

As above.

As above.

Melani (n 1 above), para 47.

Melani (n 1 above), para 48. 
the Court's order that the City's refusal or failure to apply the UISP has to be reviewed and set aside in a substantively informed order. ${ }^{43}$

\section{Concluding remarks}

The Court in the Melani case grasped the ideal of transformative adjudication by not merely applying the UISP formalistically, but also conscientiously taking account of the surrounding political and social circumstances. The Court therefore eloquently displayed transformative constitutionalism and furthered social justice by making the right of access to adequate housing realisable, aiding in the eradication of poverty and, consequentially, advancing the constitutional and progressive aspiration that is social justice. 